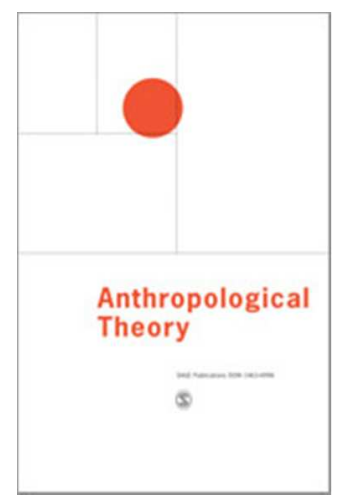

\title{
Modes of Participation
}

\begin{tabular}{|c|l|}
\hline Journal: & Anthropological Theory \\
\hline Manuscript ID & AT-17-0029.R1 \\
\hline Manuscript Type: & Article \\
\hline Keywords: & $\begin{array}{l}\text { Participation, Person, Cognition, Mind, Intersubjectivity, Transcendence, } \\
\text { Lévy-Bruhl, Durkheim, Simmel, Goffman }\end{array}$ \\
\hline Abstract: & $\begin{array}{l}\text { This paper focuses on the notion of 'participation' as it has been used in } \\
\text { the social sciences throughout the twentieth century. It proposes that } \\
\text { there are two main traditions of use-an 'individual' and a 'dividual' one- } \\
\text { and it argues in favour of the latter. It does this by examining how Simmel } \\
\text { and Goffman, on the one hand, and Lévy-Bruhl and Durkheim, on the } \\
\text { other, defined participation. Developed by Lucien Lévy-Bruhl in the first } \\
\text { part of last century, 'participation' in the dividual sense is today being } \\
\text { given new live by sociocultural anthropologists such as Marshall Sahlins } \\
\text { and phenomenologically inclined cognitive scientists such as Shaun } \\
\text { Gallagher. The paper addresses the roots of the concept in Scholastic } \\
\text { theology and proposes to show how central it can come to be to a } \\
\text { sociocultural anthropology that is willing to take on frontally the challenges } \\
\text { presently being posed by embodied cognition. }\end{array}$ \\
\hline
\end{tabular}

\section{SCHOLARONE"}

Manuscripts 


\title{
MODES OF PARTICIPATION ${ }^{1}$
}

\author{
João de Pina-Cabral \\ School of Anthropology and Conservation \\ University of Kent
}

September 2017

We are part of so many things, groups, events, occasions ... you name it. Yet, how is one 'part' of something? At first, this seems a rather inane question; but, if we attend to it a little longer, we soon come to realise that the idea of 'being part' has far greater philosophical and anthropological implications than we might have expected at first; very far from the sort of assumed simplicity that is normally attributed to it, this has been a source of philosophical debate since the days of Plato. In turn, anthropologists came upon the idea of participation at the end of the nineteenth century, and it has challenged them ever since. As this paper highlights, it turns out that the way one understands what it means to 'be part' can affect one's very central assumptions concerning social life.

Recently, the notion of 'participation' has once again come to the forefront of anthropological attention largely due to the role it plays in Marshall Sahlins' attempt to relaunch the study of kinship based on a new approach to personhood (2011a, 2011b). Originally brought to anthropology by Lucien Lévy-Bruhl at the beginning of the twentieth century ([1910] 1951), the concept was enthusiastically adopted by Émile

\footnotetext{
1 This paper was first debated at the EHESS, Paris, 01/12/2016. I am grateful to Enric Porqueres i Gené for that opportunity, as well as to Benoît De L'Estoile for a most productive stay as Invited Professor at the Ecole Normale Supérieure at that time.
} 
Durkheim (1915) and Marcel Mauss (e.g. [1926] 1967: 181). Later on, Lévy-Bruhl's use of it was also an important inspiration to Edmund Husserl in his launching of phenomenology (see [1935] 2008).

Over the years, the complex implications of participation have not escaped the attention of a few informed anthropologists. In his Morgan Lectures on magic and religion, Stanley Tambiah revisited them very insightfully (1990: 117-18), and Márcio Goldman (1994) and Frédéric Keck (2008) have provided us with studies of Lévy-Bruhl's thinking where the history of the concept of participation is valuably explored. Finally, of late, due to the impact of phenomenological insights in the study of cognition, philosophers like Evan Thompson (1997), Shaun Gallagher (Bower and Gallagher 2013) or De Jaegher and Di Paolo (2007) have been using 'participation' in ways that turn out to connect directly to contemporary anthropological interests (see Pina-Cabral 2017). In this paper, I will explore the implications of the concept of participation for social scientists (and beyond) by reference to its history, showing that we have significant lessons to learn from it. ${ }^{2}$

In the sense developed by the authors referred above, participation is initially best defined as the ambivalent encounter between the singular and the plural in the formation of the person in the world. For example, when Husserl wrote to Lévy-Bruhl to thank him for his inspiration, he explained: 'Saying 'I' and 'we,' [persons] find themselves as members of families, associations, [socialities], as living 'together,' exerting an influence on and suffering from their world-the world that has sense and reality for them, through their intentional life, their experiencing, thinking, [and] valuing." (Husserl 2008 [1935]: 2) During the first year of their lives, in acting and being acted upon together in human company, persons become 'we' at the

2 The present paper continues the discussion of these themes that I developed in Pina-Cabral 2013 and 2017. 
same time as they become ' $\mathrm{I}$ ', which means that persons will ever be both ' $\mathrm{I}$ ' and 'we' ambivalently. For so long as anthropology continues to approach the 'we' as if it were a categorical matter-a matter of 'identity' ${ }^{3}$ — rather than as concerning the presence and action of live persons in dynamic interaction with the world and each other, participation will continue to be a source of theoretical perplexity.

Husserl again explained that, "at the interactional level, intersubjectivity ... implies a kind of perspective-taking that is best characterized with metaphors such as 'trading places' rather than 'achieving understanding'." (Duranti 2010: 14) This approach captures adequately a trend that has come to the forefront over the past decade not only in sociocultural anthropology (e.g. Reyna 2002, Ingold 2010, Duranti 2010, Desjarlais and Throop 2011, Toren 2012) but also in studies of cognition (e.g. Thompson 2007, Gallagher 2009, Hutto and Myin 2013). The anthropological (see Toren 1993, 2002), psychological (see Trevarthen 1980, 1998) and philosophical evidence (see Hutto and Myin 2013, or Chemero 2009) that we possess at the moment strongly suggests that personhood is better approached not as an automatic ('natural') result of biological humanity, but as an achievement of each one of us who, during our first year of life, become persons by acquiring what the late Peirce called 'symbolic thinking' (see Short 2007).4 Throughout one's life, as we enter into further participations, this dynamic of self-constitution in the world does not stop. ${ }^{5}$ Anthropologists, therefore, are called upon to focus on personhood not as a given but as a biographical acquisition of each one of us. As Sir Raymond Firth put it so long ago in We the Tikopia (as part of

\footnotetext{
3 That is, not taking into account what Husserlians call "prenoetic constraints on perceptual experience", see Bower and Gallagher 2013, and De Jaegher and Di Paolo 2007.

${ }^{4}$ In the wake of Husserl's phenomenology, philosophers of cognition today are prone to call these modes of thinking which characterise adult persons "propositional", see Hutto 2008 and Hutto and Myin 2013.

${ }^{5}$ See "Steps of Ontogeny of Person and World" in Pina-Cabral 2017: 110-113.
} 
what we might call today his 'dwelling approach'), the culturally specific dynamics involved in personal ontogeny are an essential aspect of understanding how personhood differs in different cultures (1936: 120, 277).

The principal aim of this paper, therefore, is to examine and analyse the notion of 'being part' as when it applies to persons in ontogeny. By giving up on individuality and taking seriously the lessons on participation that the older Lévy-Bruhl left us as heritage (1949), we move to a view of personhood that helps us understand better not only the dynamics of personhood but also how these affect some of the more enduring problems that haunt our world today. ${ }^{6}$

\section{THE TWO TRADITIONS OF USE OF PARTICIPATION}

On the whole, in the social sciences over the past century, two broad traditions of use of the concept of participation can be distinctly identified. In this paper, they will be approached both by relation to the history of anthropological thinking and to their possible implications in terms of anthropological theory.

The verb 'to participate' and the expressions 'participating' and 'participation' are defined by most English dictionaries as meaning 'to share in something', 'to be involved in something', 'to share in the activities of a group'. The Thesaurus gives us a range of associated words, such as 'involvement', 'engagement', 'group action', 'commitment', 'intervention', 'intercession', 'to partake'. As a noun, the Latin particeps meant "partaker, comrade, fellow soldier"; as an adjective it implied "sharing, partaking". It is said that the verb participare found its origins in the Proto Indo-European root *kap, meaning 'to have', 'to grab', 'to share', 'to take'. However, as we

\footnotetext{
${ }^{6}$ For an argument of that point by relation to the matter of addiction and the so-called War on Drugs, see Hari 2005.
} 
will see, rather than its Latin cousin, it is the Ancient Greek word methexis ( $\mu \varepsilon \dot{\varepsilon} \theta \varepsilon \xi \varsigma$-translated by medieval philosophers as participationem) that lies at the root of the contemporary uses of the concept in philosophy.

In order to ease the exposition, I propose that there are two principal families of use relating to the words 'participate', 'participation', 'partake', or 'being part' (and, by extension, membership ${ }^{7}$ ) that have been present in the social sciences throughout the twentieth century. I call one of them the individual version and the other the dividual version, using the distinction that Marilyn Strathern brought to anthropology in her prophetic discussion of modes of personhood in Gender of the Gift (1988: 11-14). ${ }^{8}$ Whilst individuality stresses the unitary and bounded nature of entities, dividuality affirms the intrinsic plurality of what is identified as single. By dividuality, therefore, Strathern meant that, in personhood, plurality is anterior to singularity always reimposing itself.

The primary distinction between the two senses of 'being part' is that one of them assumes the individuality of the participants and, therefore, can only be applied to forms of participation where participants are accounted for as separate entities in terms of natural numbers-their essences do not merge. This is the sense that Georg Simmel explores in his groundbreaking essays (1950 [1908]). It is the meaning that is normally conveyed by the expression 'being part of which relies on a notion of a broader entity enclosing a number of smaller entities. In this more individualist usage, there is no implication of transcendence or of a mystical aspect to the relation between the participants.

\footnotetext{
7 The French word appartenance, usually translated in English as 'membership', plays such an important role in Lévy-Bruhl's personal process of unveiling the meaning of participation (1949 [1938-1939]) that it should also be included in this list.

8 Sahlins adopts it in 2011a and 2011b. The notion emerged in MacKim Marriott's treatment of Indian forms of personhood (1976).
} 
To the contrary, the dividual tradition of use does not assume the indivisibility of each participant and rather stresses the modes of constitution of participation, focusing on the more transcendent or mystical aspects of the relations that participation describes. It is generally conveyed by the expression 'being part in' (or 'participating $i n^{\prime}$ ) and it relies on a notion of things coming together without clearly determined boundaries whilst sharing their essence. In short, dividuality and its related concept of partibility involve a questioning of the very processes of generation of the entities that enter into a relation. Therefore, they see the person in terms of a dynamic of constant emergence, not as a naturally given entity existing once and for all.

As Strathern argued (1988: 14), persons are dividual to the extent that they are fusional but not symmetric; they mobilize anterior alterity, as they place the one and the many in dynamic engagement (see also Sahlins 2011b). In fact, already in his 1935 letter to Lévy-Bruhl, Husserl had made it abundantly clear that the anthropologist's propositions concerning participation in 'primitive thinking' bore profound implications for the development of a phenomenology of personhood which he was engaged in at the time (2008). No wonder, then, that the dividual tradition of use has come to be increasingly important in anthropology since the 1980s, as the latter opened itself more explicitly to the influence of phenomenology. This paper concludes not only that the (more common) 'individual' meaning of participation has implicit within it a (more complex) 'dividual' meaning, but also that the implications of this discovery can have a profound impact in how we address the world from the angle of the social sciences.

It seems important to explain from the start that the two modes are not placed here as opposites but in a continuum, to the extent that the dividual account is both more comprehensive and embraces a more 
complex set of phenomena than the individual account. In the social sciences, the two traditions of use have interacted from the very beginning, often being used indistinguishably. The first work by an anthropologist to bring specific theoretical attention to the concept was Lévy-Bruhl's Les fonctions mentales dans les sociétés inférieures (first edition 1910) and his successive books, where the word 'participation' always carries its dividual meaning. As it happens, this was the usage that inspired Durkheim towards the end of his life, as the latter explicitly tells us (Durkheim [1912] 1915: 235 n 733). As a matter of fact, in his Les formes élémentaires de la vie religieuse, Durkheim uses participation in both ways: in the individual sense, as when he says that "a certain number of individuals participate in the same moral life" (ibid.: 232); and in the dividual sense, as when he speaks of 'mystical participation' (Lévy-Bruhl's expression) when observing that Aboriginal "men are believed to participate in the nature of the animal ..." which is their totem (ibid.: 136).

According to Ann Rawls, the evolution of Durkheim's epistemological thinking at the time he wrote his last major treatise (he stopped writing soon after) was centrally marked by the notion of participation: "Durkheim argued that the principles of reason all have their origin in the moral forces experienced while participating in certain enacted practices and that knowledge derived in this way has only limited validity when applied to the natural world." (1996: 461) At the turn of the twentieth century, both Lévy-Bruhl and Durkheim faced the problem of explaining how personal sentiments and experiences coexist with collective ideologies and legalised moralities. However, as Frédéric Keck has noted (2008: 150-151), they diverged in the way they responded to this central challenge.

The Durkheimian approach (especially before the change in tone that The Elementary Forms represent) tended to be top-down, emphasizing 
more the collective representations and the categories that impose themselves on the individual, and leaving to second plan the human ethical bases of the process of constitution of personhood. For him, the group imposes itself forcefully on the individual in terms of its categories (Durkheim and Mauss 1963 [1903]). To the contrary, Lévy-Bruhl's approach remains ever attached to the level of the person's habits, usages, and sentiments; being concerned with accounting for the activity of the subjects in terms of their feelings and their personal ideas, seeing collective coordination as emerging from progressive habituation. This is what Shaun Gallagher calls participatory sense-making (2007), that is, "the coordination of intentional activity in interaction, whereby individual sense-making processes are affected and new domains of social sensemaking can be generated that are not available to each individual on their own." (De Jaegher and Di Paolo 2007: 497)

This tendency is further stressed as Lévy-Bruhl's thought evolves during the 1920s and 1930s. Deeply influenced by Maurice Leenhardt's ethnographic work on New Caledonia (e.g. Lévy-Bruhl 1949 [1938-1939]: 49-ff; Leenhardt 1979 [1947]), the older Lévy-Bruhl is less concerned with category formation and classification, since he finds that mythical thinking is not centrally moved by contradiction, classification or category formation, rather evolving on the bases of the participations of each person. Thus, he remains interested in understanding how the person confronts the social within themselves, how persons come to be collective. Like Durkheim, he sees the collective experience as essentially formative of the person, yet he does this not in terms of collective structures imposing themselves, but of humans constructing themselves as persons within social symbiosis, so to speak. He calls 'participation' to this merging of essences that occurs between people in society. 
In short, Durkheim favoured an approach that emphasizes the primacy of groupness, which he explicitly called 'sociocentrism' ([1903] 1963: 51). To the contrary, after Durkheim's death in 1917, Lévy-Bruhl evolved progressively towards a more anthropocentric approach, one that focuses on the person as the primary instance of human sociality. In this way, contrary to standard structural-functionalist understanding, Lévy-Bruhl's latter position ${ }^{9}$ approaches a phenomenological outlook in that it roots the feelings of responsibility of persons in their personal participations, seeing them as emerging separately from the formal structures of collective morality. In this way, Lévy-Bruhl's view of the relation between collective and individual morality is more akin to the personalism of Arnold Van Gennep, who Durkheim so deeply despised. As it happens, this very same approach to co-responsibility is what explains the fascination that Husserl, and later Emmanuel Lévinas, demonstrated for Lévy-Bruhl's work (see Moran and Steinacher 2008, Husserl 2008 [1935], and Lévinas 1957).

In fact, part of the reason why the late Lévy-Bruhl was by and large ignored during the second half of the twentieth century and why most anthropologists have failed to notice how creative and profound was his heuristic use of the category of 'primitive' is associated to the immense force of conviction of the sociocentric consensus that ruled our discipline during all of that time (on both sides of the Atlantic). Curiously, whilst Durkheim's early argument concerning the nature of the categories of the understanding remained solidly rooted in a set of primitivist assumptions, Lévy-Bruhl's thinking about participation evolved significantly over time and, eventually, towards the end of his life, he freed it completely from the primitivist mould (1949 [1938-1939]).

\footnotetext{
${ }_{9}$ And that of Evans-Pritchard too, contrary to what is normally assumed (see 1970 [1934]). See also Lévy-Bruhl's letter to Evans-Pritchard [1934] 1952.
} 


\section{DIVIDUAL PARTICIPATION}

Lévy-Bruhl's initial observation-emergent from his attentive reading of the ethnographic work that was coming out in the decade leading to the First World War-was that participation as a principle of 'primitive mentality' counters the 'laws of contradiction' which shore up modern logic (1910). From the beginning, he qualified this kind of participation as being 'mystical'. But it must be stressed that, for him, the word 'mystical' did not refer to some sort of spiritual event. Rather, it aimed to describe something both he and Mauss repeatedly observed: persons in these 'primitive' societies were not 'individual' in that they participated in other persons and in things in ways that conjoin emotion with transcendence. Transcendence is used here in a Kantian sense to imply a capacity to move beyond physical existence, not in some deist or spiritual sense. As a matter of fact, it can be argued that this was also Mauss' main discovery in his essay The Gift, where he observes that a given object takes with it a part of the giver with profoundly emotional and transcendental implications (2016 [1925]).

It seems important, therefore, to note that Lévy-Bruhl's very choice of the word 'participation' was inspired by an old metaphysical tradition that pointed him in this direction. In Ancient Greek theatre, the concept of $\mu \dot{\varepsilon} \theta \varepsilon \xi ı$ (participation) was originally used to refer to the way in which the audience interacted with the actors, thus affecting the development of a play. With Plato, however, a tradition was started of attributing an ontological meaning to 'participation', that is, one that relates it to the nature of being. For him, in the famous allegory of the cave, participation was the relation between changing things (observable particulars) and the changeless forms (the Ideas) that gave them their being: "we generally postulate a certain form or character-a single form or character, always- 
for each plurality of things to which we give the same name." (Republic X, 596a) In time, Aristotle criticised this idea, saying that he cannot attribute any meaning to the relation that particulars have with forms ("sharing means nothing", he says in Metaphysics VIII, 6). With him, participation gets to be closer in meaning to causality, by reference to the way effects 'participate' in their causes. This is the usage that came to influence St. Augustine and subsequent Christian theology.

More broadly, in etymological terms, “ $\mu-\theta \varepsilon \xi \iota \varsigma$ bespeaks plurality, similarity, relation and asymmetry all at once. ... To speak of metaphysical participation is to say that one thing has what it is with and indeed after and in pursuit of, another: it has its reality, in other words, by virtue of something other than itself." (Schindler 2005: 1) Schindler further clarifies that "a reference to 'parts' is not [an] ingredient in the Greek term as it is in the Latin ... We ought not to let this root lead us to envision the participatum [the form in which particulars participate] as having discrete parts, which is clearly excluded by the metaphysical use of the concept, i.e., meaning the sharing in a (metaphysically) simple quality" (ibid.: 1, fn 1).

I do not presume to revisit here the long and extremely complex history of the c0ncept, except to trace the more immediate inspiration for the use of the term by Lévy-Bruhl (and subsequently the late Durkheim). As he uses it in Les fonctions mentales dans les sociétés inférieures, his first book on the topic, Lévy-Bruhl appears to have taken the word from the work of Nicolas Malebranche, a late seventeenth century philosophertheologian who attempted to merge Neo-Platonist theology (inspired by St. Augustine and St. Thomas Aquinas) with Cartesian rationalism. Lévy-Bruhl attributes to Malebranche the expressions 'participable individuals' ([1910] 1951: I/II, 69) and 'the living are participated by the dead' ([1910] 1951: III/IV, 86)—notions that would come to have a long and influential 
life in twentieth century anthropology, usually unbeknownst to their users.

For Malebranche, participation compounded sharing of essence ${ }^{10}$ with causality of being: "God does not derive his being from the creatures; rather it is the creatures that are nothing but imperfect participations of the divine being." ([1674-75] 1910: 330, my translation) In this way, and following on St. Augustine's interpretation, to be is a matter of degree, since God is taken to be not only the ultimate cause but the highest instance of being: "Since God is the highest essence (summa essencia), that is, he is in the highest degree and thus is immutably, He has given being to the things He has created from nothing, but not Being in the highest degree such as He is." 11

Twentieth century usages of participation in anthropology and phenomenology are, therefore, inspired by Aquinas' latter doctrine of participation (as exemplified in his commentary on Boethius' De hebdomadibus, 2001 [1271-2]), where being, living, and understanding (esse, vivere et intelligo) are presented as interconnected. Aquinas differentiates existence (esse, the act of being) from essence (essencia, the truth of a proposition), but in God this difference disappears. We cannot know God's existence directly, he claims, since we are its effects; "we know that God is, because we conceive this proposition in our mind from His effects." 12 An effect participates in its cause, not the other way round. In Neo-Platonist thought, therefore, by identifying sharing of essence with causality of existence, participation acquires a kind of unidirectionality.

It is this same concept of participation that is going to inspire Lévy-

\footnotetext{
10 The word 'essence' (the what-ness or quiddity of a thing) is used here in the sense that Thomas Aquinas attributes to it when he says "the essence [essencia] is that which is signified by the definition of a thing." (1997 [1252-53], chap. 2)

${ }^{11}$ From St. Augustin's De Civitate Dei, 12:2, as translated by Schultz and Synan-in Aquinas 2001: xxi.

12 As instantiated in the Ontological Proof of God's existence (see Pina-Cabral 2017: 52-ff)—from Quaestio Disputatae De Potentia Dei, q. 7, a.2, ad1:

http://www.logicmuseum.com/wiki/Authors/Thomas_Aquinas/depotentia/Q7\#q7a2tit1
} 
Bruhl's reading of the ethnographic literature available at the turn of the twentieth century. Notably exemplified by the Bororos' claim that they are macaws (arara), he observes that a person "frequently experiences participations between himself and this or that environing being or object, natural or supernatural, with which he is or comes to be in contact, and (...), quite as frequently, he imagines similar participations between these beings and objects" ([1910] 1951: 77-78).

This leads him to formulate his famous 'law of participation' where the Durkheimian notion of 'collective representation' plays the role of the NeoPlatonist God: "all of these [examples] imply a 'participation' among beings or objects brought together under a collective representation." (ibid.: 76) He identified a similar kind of unidirectionality akin to that of Aquinas' participation in God by His creatures. Thus, there was a sociocentric implication to Lévy-Bruhl's initial notion of participation in that 'Society' (placed now in Comtian fashion in the position where God used to be) both transmitted essence and produced existence: "The very existence of social groups, in their relations with the existence of the individuals who compose them, is most often represented (and felt at the same time as represented) as a participation, a communion, or better still as a complex of participations and communions." (ibid.: 93)

However, over the following three decades, as his thinking progressively dissociated itself from the initial Durkheimian influenceand particularly at the end of his life, inspired by the evidence provided by the great ethnographers of the Classical Period (from the late 1920s to the early 1950s)-Lévy-Bruhl comes to abandon this directionality of participation in favour of a multidirectionality of participation, where beings and objects participate in each other in complex webs of mutual influence and implication. The sociocentric notion that 'society' 
(groupness) is both the cause and the essence of the participation is pushed to a second plan in favour of an approach that attributes greater centrality to the constitution of the person in time. This is not to say, as Sahlins notes, that participation cannot also assume the form of "the encompassment of others" in typically hierarchical relations (Sahlins 2011a: 13). Indeed, the emergence of the person in early ontogeny is a form of encompassment of others, since it occurs in a context of copresence where singularity and plurality are jointly operative (see Hattiangadi 2005).

In the course of the 1930s, as his thought evolves and as he collects further ethnographic examples, Lévy-Bruhl drops the central notions that had initially launched his project: both that of 'primitive' and that of 'prelogical'.13 He never abandons the preoccupation with describing how humans have different outlooks on reality and that these must be studied as different-the founding call of all anthropology, one might say. But he comes to understand that all forms of human thinking are foundationally related among them by some basic disposition of humans to make sense of the world in participation with each other. The concept of participation, thus, comes to assume a central importance in describing how this basic disposition operates, and it comes to play for him a foundational role.

He explicitly lets us know that one of the important turning points in his thinking was an essay on "Physics and Reality" that Albert Einstein wrote in 1936, when he was an exile in Paris. There, the physicist argues:

One may say 'the eternal mystery of the world is its comprehensibility'. ... In speaking here of 'comprehensibility', the expression is used in its most modest sense. It implies: the production of some sort of order among sense impressions,

\footnotetext{
13 "Today-and this is surely a progress-I no longer search for a difference between primitive mentality and ours from a logical point of view." (Lévy-Bruhl, 1949: 71, my translation) Why authors like Ann Rawls fail to register this evolution, preferring to ignore Lévy-Bruhl's crowning achievements as inscribed in his posthumously published Notebooks, is puzzling to me (Rawls 1996: 462). As it happens, this is just the contrary of what she does for Durkheim, whose evolution is her central theme.
} 
this order being produced by the creation of general concepts, and by definite relations of some kind between the concepts and sense experience. It is in this sense that the world of our sense experiences is comprehensible. The fact that it is comprehensible is a miracle. ([1936] 1954: 292)

Lévy-Bruhl is struck by Einstein's argument that this "intelligibility ${ }^{14}$ of the world of the senses that science orders and sets to rules is in itself ultimately unintelligible." (1949: 49) Thus, he is led to contemplate that the difference between 'primitive' thought and 'our' thought would be "simply one of degree" (ibid.). By conjoining Einstein's observation with Leenhardt's ethnographic evidence concerning the person in New Caledonia (in the reading of which he was deeply immersed at the time), he abandons his original preoccupation with 'logical meaning'. He now sees that conceptual (propositional) thinking-as in scientific explanation-sits on top of a more basic form of construction of meaning, one that depends centrally on the person's engagement with the world and others in the course of personal ontogeny and that, consequently depends on what he calls sentiments (Fr. feelings/affects). In order to describe this participatory sense-making, Lévy-Bruhl takes recourse to the Kantian notion of 'orientation', that is, "the logic of affect [which] corresponds to an action of the body towards things and not an abstract reasoning." (Keck 2008: 139)

In this way, Lévy-Bruhl moves beyond the polarisation of 'primitives' and 'us'. His answer is that 'participation' (and its corresponding 'orientations') is at the root of all thinking. Persons are surrounded by appartenances, that is, things and persons in which they participate and which give sense to their world. He tells us that he can best qualify

\footnotetext{
${ }^{14}$ Einstein's original word was Begreiflichkeit, for which the translator uses the word 'comprehensibility' when Lévi-Bruhl's 'intelligibility' would seem to do just as well.
} 
'participation' by the etymological meaning of sympathy, a 'feeling with' (1949: 59). We will have to wait for yet another half century before people like Varela (cf. Varela, Thompson and Rosch 1991) and Damásio (1999) come to argue that emotion cannot be separated from cognition, thus corroborating Lévy-Bruhl's profound insight.

Lévy-Bruhl goes on to differentiate between conceptual thinking (what philosophers of cognition now call 'propositional thinking', see Hutto 2008) and participation: "Participation has no reality other than in being felt by an individual ... It is therefore an event ... localised in space and time or, better said, has its own space and its own time. This means that ... there are no contradictions but only contrasts; events are composed one with the other, or oppose each other more or less strongly; as they are felt in their own space and time, they cannot exclude each other." (1949: 51, my translation) In this way, he moves to abandon his original conception that there would be a "law of participation" that would be the foundation of primitive thinking as the Aristotelian "laws of contradiction" are the foundation of modern logic. Rather, participation becomes for him a general fact of human experience: "What remains is the fact (not law) that the 'primitive' often experiences participations between himself and this or that surrounding being or object, of a natural or supernatural kind, with which he is or enters into contact, and that, just as frequently, he imagines such participations between beings and objects ... " (ibid.: 52). The feeling of participation has a "fundamental character" (ibid.: 69). The participations people experience, therefore, are not experienced as part of rational deliberation but as facts of experience that ground conceptual elaboration, they are more akin to perception than to thought.

As he himself abandoned the sense of metaphysical unidirectionality of participation that he had inherited from Malebranche and the Comtian 
tradition, so did most anthropologists that came to use the notion of participation in the second half of the twentieth century. Stanley Tambiah, for example, makes a singularly valuable contribution to this discussion, which is informed already by the reading of Donald Davidson and other philosophers of the period (1990: 117-18). While-much like Sahlins (2011a, 2011b) - he stresses that participation is at the root of kinship, Tambiah shows how it "emphasizes sensory and affective communication and the language of the emotions" (1990: 108). Thus, he claims, it is the basis of religious or magical phenomena. This is how Tambiah redefines Lévy-Bruhl's concept: "Participation can be represented as occurring when persons, groups, animals, places, and natural phenomena are in a relation of contiguity, and translate that relation into one of existential immediacy and contact and shared affinities" (ibid.: 107). By taking recourse to the word "existential" - which was by then a recognisable concept in general social scientific jargon-Tambiah is attempting to bypass the phenomenological complexity of what he is actually conveying.

Unfortunately, once again, as in the case of Lévy-Bruhl's editor Bruno Karsenti (1998), Tambiah adopts the characteristic midcentury representationist and sociocentric approach, where both groups and persons are held to hold 'representations' and these are considered to be phenomena of the same nature. In light of the critique of this model of mind that the theories of embodied cognition represent (e.g. Chemero 2009), we are faced today with the challenge of matching Lévy-Bruhl's profound insights concerning participatory sense-making with contemporary approaches to cognition.

INDIVIDUAL PARTICIPATION 
Before moving on, however, it seems important to consider the alternative tradition of use of the concept of participation. I trace the principal input towards an individual use to the deep influence of the German sociological school in the English-speaking world at mid-century. For example, if we run through the English translation of Max Weber's Economy and Society, we will not find a single instance in which the word 'participation' is used in its dividual sense. ${ }^{15}$ His holding on to a consistently individualist understanding of what it is to be human is similarly reproduced in Georg Simmel's highly influential works, where personal interaction is understood as a form of coordination among individuals.

The primary instance must surely be Simmel's seminal essay "Quantitative Aspects of the Group" ([1908] 1950: 87-180). From its original translation into English in Chicago in 1950, this essay became a central reference for sociological thinking (and we cannot discount the decisive impact that this ontological background had in American cultural anthropology in the second half of the twentieth century through Talcott Parsons' formative influence on Clifford Geertz and David Schneider ${ }^{16}$ ). The essay's starting premise is the unquestioned unicity of the individual. Whilst Simmel perceives clearly that 'group form' can only be achieved when there are more than three persons involved, this insight is not accompanied by a questioning of the nature of the relation between the singular and the plural. The naturalization of the person as individual prevents him from granting anteriority to alterity and means that he founds his sociology on a form of theoretical individualism. The theme of intersubjectivity does not play a role in his analysis and the properties that intersubjective relations are normally held to possess are treated by him as

\footnotetext{
${ }^{15}$ Although there is a curiously undeveloped reference to 'sympathetic participation' (1978: I, 5).

16 See Sahlins: "Schneider was trained in an era of social science hubris that from its centre in the lesser Cambridge spread its Parsonian doctrine that any differences that could be 'usefully' discerned in the object of anthropological study were legitimate analytic distinctions." (2011:6)
} 
features of 'small groups' — ones, dyads, and triads—by opposition to larger groups.

As it happens, however, we find in Simmel's essay the marks of a struggle with the uncomfortable possibility of personhood being a complex, constructed process-not being, in fact, fundamentally individual. For example, he meets with the problem when attempting to resolve the matter of personal reflexivity (that is, a person's knowledge of him or herself as person): "Morality", he argues, "develops in the individual through a second subject that confronts him in himself. By means of the same split through which the ego says to itself 'I am'-confronting itself, as a knowing subject, with itself as a known subject-it also says to itself 'I ought to'. The relation of two subjects that appears as an imperative is repeated within the individual himself by virtue of the fundamental capacity of our mind to place itself in contrast to itself, and to view and treat itself as if it were somebody else." (ibid.: 99) The feat of reflexivity is portrayed here as a 'capacity of the mind' that allows for the constitution of the person, not as a feature of the whole person in ontogeny. Yet, whilst personhood implies reflexivity, it is not preceded by it.

Therefore, after this passage, Simmel feels he needs to make a caveat. "I do not here answer the question whether this phenomenon represents a transference of the empirically prior interindividual relation to the elements within the individual, or whether it is a purely spontaneous process originating in these elements." ([1908] 1950: 99) Much as he might want to avoid it, the matter of what kind of 'elements' we are dealing with, cannot be avoided. If, indeed, either 'interindividuality' is anterior to individuality or personhood is composed of elements, then the question is what are these parts and how do they come to form an 'individual' entity. In short, what this discussion clarifies is that the questions posed by dividual 
participation lay dormant within the sense of individual participation that modernist sociology favoured. There is, one is tempted to say, a metaphysical act of faith at the root of Simmel's sociology.

Here, we are not very far from the well-known and much debated metaphysical problems that the 'origin of social facts' posed to persons such as Comte, Durkheim, or Lévi-Strauss (e.g. Badcock 1975: 33). The recourse to the notion of gestalt in explaining the individuality of both persons and groups is, after all, a version of the same problem. ${ }^{17}$ That is, one would want individuals to form what G.E. Moore called 'external relations', that is, a situation where the entities are not constituted by the relations (1919). But social life provides us constantly with examples of the contrary and, thus, in order to explain the dividuality of the supposedly individual entities, Comte, Simmel or Durhkeim were faced to undertake this metaphysical leap.

For example, when considering the commonly encountered example of institutions (such as committees or administrative bodies) being named by the number of their constituent parts, Simmel remarks that "the idea expressed by this sum is the functional interactive togetherness of the group" (1950: 107). Thus, when the institution is known by a name referring to a number, such as 'Six' for a committee composed of six members, this "does not refer to six individual and isolated elements but to their synthesis. 'Six' is not ' 1 plus 1 plus 1,' etc., but a new concept emerging from the synthesis of these elements: it is not, so to speak, proportionally present in each of them." (ibid., my emphasis) Note how he pushes the problem aside by talking of a concept, yet, the matter was not how an observer thinks of an institution, but how the institution actually acts as an institution; its features quainstitution.

17 I suppose that Rawls would call this the relation between Durkheim's epistemology and his sociology of knowledge (1996). 
Erving Goffman is probably, among all sociologists, the author who prolonged more creatively this line of reasoning. As in Simmel's, in his work, participation assumes implicitly both the pre-existence of the group to the interaction, and the pre-existence of the person (the individual) to the interaction-none of which is the case with Lévy-Bruhl's approach. In Goffman's analyses, the self sits like a dress or a mask upon the person who, conceived as individual, is presented as ultimately natural. Participation is the occurrence of a joint effort on the part of individuals who find themselves involved in social activities that are given to them largely as an option. So Goffman accepts that the 'selves' actually are constituted in the moment, but he does not see them as the essence of what is at stake. The essence lies in the individual who is always taken to be previously existent. For Goffman, individuals do not participate as total persons; selves sit on top of individuals like they were dresses or skins guiding their participation: "during face-to-face encounters individuals may participate officially in more than one capacity"([1967] 2005: 52).

Goffman's more elaborate treatment of the issue of participation can be found in his long essay "Footing" ([1967] 2005). Here, participation is initially used in its individual sense. However, as is so often the case with Goffman, as his arguments evolve concerning how humans interact linguistically, the dividual meaning starts to emerge. Towards the end of the paper, it becomes obvious that the two meanings of 'being part' are essentially interdependent. ${ }^{18}$

The subject of the paper is how humans talk. Goffman starts from the assumption that the units of 'talk' are individuals-they are natural and pre-existent. In fact, when he speaks of 'official participants', 'ratified participants', or 'adventitious participants', he is assuming that these are

\footnotetext{
${ }^{18}$ For a similar condition, see Goodwin and Goodwin 2004.
} 
individual-that is, fully self-defined, clearly identifiable, and neatly bounded units of social interaction whose bodily boundaries constitute their essential determination. However, soon enough, he realizes that his default approach to human communication-which assumes that the participants in 'talk' are clearly determined individual units-misinterprets seriously what actually is going on when humans talk: "the common dyadic model of speaker-hearer specifies sometimes too many, sometimes too few, sometimes the wrong participants." ([1967] 2005: 145) He shows that, as speakers, "it is not true to say that we always speak our own words and ourself take the position to which these words attest" (ibid.: 146); and, as hearers, we conceal "a complex differentiation of participation statuses" (ibid.). As he puts it, "if language is to be traced back to some primal scene, better it is traced back to the occasional need of a grunted signal to help coordinate action in what is already the shared world of a joint task than to a conversation in and through which a common subjective universe is generated." ([1967] 2005: 141) In short, when we are dealing with interactions among persons in ontogeny, to be 'one of many' and to 'merge with others' are activities that seldom can be clearly distinguished, because the nature of the subject is dependent on the interaction and cannot be considered a pre-given.

In human talk, singularity and plurality (the 'I/me' and the 'we') are constantly shifting and dyadic confrontation always remains unstable (see Strathern 1988:11-14). In sum, Goffman remains bound by an individualist view of personhood, where an individual sense is the default assumption, but he opens up a window towards a more dividual sense of participation, corresponding to a fusional process of sharing of essences. The individual mode of approaching participation turns out to be a subcategory of the dividual (phenomenological) meaning of the expression. The presence of a 
more dividual understanding of what it means to participate ultimately imposes itself.

In this way, we make way for something that Goffman, quite as much as Lévy-Bruhl, had identified but struggled to formulate: the possibility of a person being itself and another. This, in fact, corresponds to one of more profound insights of the late Lévy-Bruhl:

What turns participation into something that appears to be irreconcilable with the habitual norms of the intellect, is that, without realizing it, we assume that, in primitive mentalité, beings are first given and then participate of this or that other person, of this or that supernatural force, etc.-without our being able to understand how this participation can be established, how a being can be at the same time itself and another ... (1949:250).

Thus, he inverts the traditional individualist perspective on personal constitution. Persons are no longer seen as "beings [that] are given beforehand and then enter into their participations" (1949: 250). Rather,

Participation is not simply a mysterious and inexplicable fusion between beings who lose and keep at the same time their identity. It enters into the constitution of these same beings. Without participation they would not have been a given of their own experience: they would not have existed. ... Participation, therefore, is immanent to the individual as he owes what he is to it. (1949:250, my emphasis)

Thus, he concludes, "it is impossible for the individual to separate in himself what is properly his and that with which he participates in order to exist" (1949: 251). Dividual participation, therefore, is the groundwork upon which everyday social interaction is constituted. All individualist uses of participation-much as they might appear to simplify mattersultimately meet up with the problem of explaining how the participants are constituted as participants. This is the challenge that both Lévy-Bruhl and Sahlins were led to face. 


\section{CONCLUSION}

The notion that sociality is a cover (a role, a mask, a veil) that we place over our essential natural individuality is a deeply engrained background assumption of the social sciences. We are unwitting heirs to a centuries' old heritage that sees human thinking as the operation of the 'soul/spirit' (Givens 2009) - that is, mind is something that occurs inside each one of us in separation from our body (albeit related to it in some usually unfathomable way via the emotions). Although most anthropologists have been for many decades conscious of the need to dispense with categories such as spirit or soul, they have been insufficiently watchful of the fact that their representationist background assumptions depend on such categories (see Spackman and Yanchar 2015, Pina-Cabral 2017).

From the days of Tylor, anthropologists have believed that 'others' are animists, not 'us'; a discussion that has lately been relaunched in interesting new terms (see Descola 2013). Nevertheless, the assumption that 'they' (those whom our predecessors called 'primitives') are animists whilst 'we' are materialists needs to be fundamentally questioned. As it happens, 'we' are the main culprits of animism in that we are the ones that assume that our bodies are inhabited by (conscious, reasonable, ethical) spirits. As I have extensively argued elsewhere (see Pina-Cabral 2017), anthropologists have continued to work unwittingly with notions of thought as representation that have prevent them from exploring as profoundly as is needed the full implications of embodiment. Lévy-Bruhl's notion of participation, in that it connects dynamically personhood with sociality, is a door that allows us to explore creatively new fields of anthropological analysis.

As persons, we are always almost-one (partible) and slightly more 
than one (dividual). The anthropological, psychological (see Trevarthen 1980, 1998) and philosophical evidence (see Hutto and Myin 2013, or Chemero 2009) that persons are both partible and dividual and that personhood is not an automatic (natural) result of biological humanity is overwhelming since before the days of Lévy-Bruhl (see, for example, Firth's debate on personal ontogeny in his Tikopia ethnography, 1936). The problem, then, is that too many anthropologists have been unwilling to contemplate that the world really does not turn out to be the way our ancestors had conceived it. Anthropologists are loath to admit that there is no essentiality to personhood-individuality remains the default mode. They lack the courage of Lévy-Bruhl and, in fact, they prefer to deride him as somehow 'ethically' culpable!

Yet it turns out that the notion of individuality is as wrong when applied to persons as when it is applied to rats or amoebas (see LéviStrauss 2000, Pina-Cabral 2017: 138-142). Live beings are not monads; they are not little pellets of meaning that some demiurge produces out of some ethereal machine. Live beings are emergent properties in the process of life; they are processually constituted and cannot ever be dissociated from life's dynamism, their mind is a function of their embodiment (see Thompson 1997). Sociality, therefore, is not a force that is superimposed on life, as Durkheim depicted it. Rather, sociality—the capacity to address the world with a purpose in order to survive as a species-is the basic condition of life (as Bateson defended a long time ago, 1972). The complex sociality of dolphins and primates is an emergent property within sociality more generally (see Hattiangadi 2005), and so is personhood, a condition that only embodied humans who actively participate in the world with other humans can fulfill. 


\section{REFERENCES}

Aquinas, Thomas. [1252-53] 1997. De Ente et Essentia, ad fratres et socios suos. Transl. Robert T. http://www.logicmuseum.com/wiki/Authors/Thomas Aquinas/esse es sentia

Aquinas, Thomas. [1271-72] 2001. An exposition of the On the hebdomads of Boethius. Trans. Janice L. Schultz and Edward A. Synan. Washington, D.C.: The Catholic University of America Press.

Badcock, C. R. 1975. Lévi-Strauss: Structuralism and Sociological Theory. London: Routledge.

Bateson, Gregory. 1972. Steps to an ecology of mind: Collected essays in anthropology, psychiatry, evolution, and epistemology. Chicago: University of Chicago Press.

Bower, M. and Shaun Gallagher. 2013, 'Bodily affects as prenoetic elements in enactive perception', Phenomenology and Mind 4 (1): 78-93.

Chemero, Anthony. 2009. Radical embodied cognitive science. Cambridge, MA: MIT Press.

Damásio, António. 1999. The feeling of what happens: Body, emotion and the making of consciousness. London: Vintage.

De Jaegher, Hanne and Ezequiel di Paolo. 2007. "Participatory SenseMaking: An enactive approach to social cognition" Phenomenology and Cognitive Science 6: 485-507.

Descola, Philippe. 2013. Beyond nature and culture. Trans. Janet Lloyd. Chicago: University of Chicago Press.

Desjarlais, Robert and C. Jason Throop. 2011. "Phenomenological Approaches in Anthropology". Annual Review of Anthropology 40: 87102.

Duranti, Alessandro. 2010. "Husserl, intersubjectivity and anthropology" 
Anthropological Theory 10 (1): 1-20.

Durkheim, Émile and Marcel Mauss. [1903] 1963. Primitive classification. Trans. Rodney Needham. Chicago: University of Chicago Press.

Durkheim, Emile. [1912] 1915. The Elementary Forms of the Religious Life. Trans. Joseph Ward Swain. London: Allen \& Unwin.

Einstein, Albert. [1936] 1954. "Physics and Reality" in Ideas and Opinions, pp. 290-323. New York: Three Rivers Press.

Evans-Pritchard, E.E. [1934] 1970. "Lévy-Bruhl's theory of primitive mentality." Journal of the Anthropological Society of Oxford 1 (2): 39-60.

Firth, Sir Raymond. 1936. We the Tikopia: A Sociologica Study of Kinship in Primitive Polynesia. London: Allen \& Unwin.

Gallagher, Shaun. 2007. "The shadow of the transcendental: Social cognition in Merleau-Ponty and cognitive science" in K. Novotny ed. Corporeity and Affectivity. Prague: Brill.

Gallagher, Shaun. 2009. "Two problems of intersubjectivity" Journal of Consciousness Studies 16 (6-8), pp. 289-308.

Givens, Terry. 2009. When souls had wings: Pre-mortal existence in Western thought. Oxford: Oxford University Press.

Goffman, Erving. [1967] 2005. "Footing" in Interaction Ritual: Essays in Face to Face Communication, pp. 105/6. Chicago: Aldine.

Goldman, Márcio. 1994. Razão e Diferença: afectividade, racionalidade e relativismo no pensamento de Lévy-Bruhl. Rio de Janeiro: Grypho.

Goodwin, Charles and Marjorie H. Goodwin. 2004. "Participation" in $A$ companion to linguistic anthropology, Alessandro Duranti (ed.), pp. 22244. Oxford: Blackwell.

Hari, Johann. 2015. Chasing the Scream: The First and the Last Days of the War on Drugs. London: Bloomsbury Publishers.

Hattiangadi, Jagdish. 2005. "The emergence of minds in space and time" in 
The mind as a scientific object: Between brain and culture, Christina E. Erneling and David Martel Johnson (ed.s), pp. 79-100. New York: Oxford University Press.

Heidegger, Martin. [1929/30] 1995. The fundamental concepts of metaphysics: World, finitude, solitude. Transl. William McNeill and Nicholas Walker. Bloomington: Indiana University Press.

Husserl, Edmund. [1935] 2008. "Edmund Husserl's Letter to Lucien LévyBruhl" The New Yearbook for Phenomenology and Phenomenological Philosophy 8 (1): 161-165.

Hutto, Daniel. 2008. Folk psychological narratives. Cambridge, MA: MIT Press.

Hutto, Daniel, and Erik Myin. 2013. Radicalizing enactivism: Basic minds without content. Cambridge, MA: MIT Press.

Ingold, Tim 2010. "The man in the machine and the self-builder." Interdisciplinary Science Review 35 (3-4): 353-64.

Karsenti, Bruno. 1998. "Présentation" in Les carnets de Lucien Lévy-Bruhl, Bruno Karsenti (ed.), pp. i-xxxvii. Paris: PUF.

Keck, Frédéric. 2008. Lévy-Bruhl: Entre philosophie et anthropologie. Paris: Éditions CNRS.

Leenhardt, Maurice (1979 [1947]) Do Kamo: Person and Myth in the Melanesian World. Chicago: University of Chicago Press.

Lévi-Strauss, Claude. 2000. "Apologie des amibes" in En substance: Textes pour Françoise Héritier, Jean-Luc Jamard, Emmanuel Terray, and Margarita Xanthakou (ed.s), pp. 493-96. Paris: Fayard.

Lévinas, Emmanuel. 1957. "Lévy-Bruhl et la philosophie contemporaine". Revue Philosophique de la France et de l'Étranger 147: 556-569.

Lévy-Bruhl, Lucien. [1910] 1951. Les fonctions mentales dans les sociétés inférieures. Paris: PUF. 
Lévy-Bruhl, Lucien. [1934] 1952. "A letter to E. E. Evans-Pritchard." British Journal of Sociology 3 (2): 117-23.

Lévy-Bruhl, Lucien. [1938-1939] 1949. Carnets. Paris: PUF.

Mariott, McKim. 1976. "Hindu transactions: Diversity without dualism." In Transaction and meaning, edited by Bruce Kapferer, 109-42 (ASA Essays in Anthropology 1). Philadelphia: ISHI Publications.

Malebranche, Nicolas. [1674-75] 1910. De la Recherche de la Verité. Paris: Garnier Frères.

Mauss, Marcel. [1926] 1967. Manuel d'ethnographie. Paris: Ed.s sociales.

Mauss, Marcel [1926] 2016. The Gift: Expanded edition. Jane Guyer transl. and ed. Chicago: HAU Books.

Moore, George E. 1919. "External and internal relations." Proceedings of the Aristotelian Society (N.S.) 20: 40-62.

Moran, Dermot and Lukas Steinacher. 2008. "Edmund Husserl's letter to Lucien Lévy-Bruhl: Introduction" New Yearbook for Phenomenology and Phenomenological Philosophy 8 (1): 325-347.

Pina-Cabral, João. 2009. "The all-or-nothing syndrome and the human condition" Social Analysis 53 (2): 163-176.

Pina-Cabral, João. 2017. World: An anthropological examination. Chicago: Hau Books.

Rawls, Anne W. 1996. "Durkheim's Epistemology: The Neglected Argument" American Journal of Sociology 102 (2): 430-482.

Reyna S. 2002. Connections: Brain, Mind, and Culture in Social Anthropology. London: Routledge.

Sahlins, Marshall. 2011a. "What is kinship (part one)." Journal of the Royal Anthropological Institute (N.S.) 17 (1): 2-19.

Sahlins, Marshall. 2011b. "What is kinship (part two)." Journal of the Royal Anthropological Institute (N.S.) 17 (2): 227-42. 
Schindler, David C. 2005. "What's the Difference. On the Metaphysics of Participation in a Christian Context" The Saint Anselm Journal 3 (1): 127.

Short, T. L. 2007. Peirce's theory of signs. Cambridge: University Press.

Simmel, Georg. 1950 [1908] The Sociology of Georg Simmel. Glencoe, Ill.: The Free Press.

Spackman, Jonathan and Stephen C. Yanchar. 2015. "Embodied Cognition, Representationalism, and Mechanism: A Review and Analysis". Journal for the Theory of Social Behaviour 44(1): 46-79.

Strathern, Marilyn. 1988. The gender of the gift. Berkeley: University of California Press.

Tambiah, Stanley J. 1990. Magic, science, religion, and the scope of rationality (Lewis Henry Morgan Lectures 1984). Cambridge: University Press.

Thompson, Evan. 2007. Mind in life: Biology, phenomenology, and the sciences of mind. Cambridge, MA: Belknap for Harvard University Press.

Tomasello, Michael. 2008. Origins of human communication. Cambridge, MA: MIT Press.

Toren, Christina. 1993. "Making history: The significance of childhood cognition for a comparative anthropology of mind." Man (N.S.) 28 (3): 461-78.

Toren, Christina. 2002. "Anthropology as the whole science of what it is to be human." In Anthropology beyond culture, edited by Richard G. Fox and Barbara J. King, pp. 105-24. London: Berg.

Toren, Christina. 2012. "Imagining the world that warrants our imagination-The revelation of ontogeny." Cambridge Anthropology 30 (1): 64-79.

Trevarthen, Colwyn. 1980. "The foundations of human intersubjectivity: 
Development of interpersonal and cooperative understanding in infants" in The social foundations of language and thought: Essays in honour of J. S. Bruner, David R. Olson ed., pp. 316-42. New York: Norton.

Trevarthen, Colwyn. 1998. "The concept and foundations of infant intersubjectivity" in Intersubjective communication and emotion in early ontogeny, Stein Bråten ed., pp. 15-46. Cambridge: Cambridge University Press.

Weber, Max. 1978. Economy and Society: An Outline of Interpretive Sociology. Guenther Roth and Claus Wittich ed.s. 2 vol.s Berkeley: University of California Press.

Varela, Francisco, Evan Thompson, and Eleanor Rosch. 1991. The embodied mind: Cognitive science and human experience. Cambridge, MA: MIT Press. 